\title{
Rethinking the Concept of Seafaring Labor
}

\author{
XU Tie ${ }^{1}$ and ZHANG Pengfei ${ }^{2}$ \\ 1. Captain and Senior Lecturer of Merchant Marine College, Shanghai Maritime University, Shanghai 201306, China \\ 2. School of Maritime Science and Engineering, Southampton Solent University, UK SO140YN
}

\begin{abstract}
In the maritime industry, seafaring labor is the most important part of the process of shipping production, just as much as the factory worker on land. However, due to seafaring is, in its most part, not possible to compare with occupations on land, the seafaring labor also very much differs from that of shore based workers. On the one hand, the seafarer's profession is still one of the most complex and dangerous work with unmatched rates of intrinsic hazards. On the other hand, the ship is not only the special instrument of seafaring labor, but also the residence where the seafarer is working, living, sleeping and socializing. All these characteristics determine that the policies and practices in respect of the seafarer differ from that in shore based industry. From the perspective of mode of production and labor process, a number of characteristics of seafaring labor are discussed in this article.
\end{abstract}

Key words: Seafarer labor, characteristics, production.

\section{Introduction}

The role of seafaring production is vital to society in general and to commerce in particular as it carries some $90 \%$ of internationally traded produce (Alderton \& Winchester, 2001). Compared with industry on the land base, there are a number of special characteristics in the seafaring production. Therefore it has always been treated as a special industry in the world.

In Marxist theory, human society consists of two major components: the base (also be called economic base) and superstructure (ideological superstructure) [1]. The base, consisting of productive forces and relations of production, is the underlying economic foundation of all societies and the part on which the other parts of society rest and depend. The superstructure consists of everything not in the base, especially politics, law, policy, culture and religion [2]. The base determines the superstructure, and the superstructure often influences and stabilizes the base [3]. In order to promote the development of social production, the determined superstructure should adapt to the determining economic base [4]. In the maritime

Corresponding author: ZHANG Pengfei, Dr., master mariner and maritime lawyer, research fields: nautical science, maritime law, shipping business. society and shipping production, the marine policy and regulatory system, as one part of superstructure, should adapt to and promote the economic base.

This paper draws together themes from different aspects in the mode of seafaring production. It represents the first coherent attempt to summarize up the special characteristics of seafaring labor in the modern maritime industry from the perspective of economic theories. In the limited space available in this paper, it would be an ambitious task to tough upon every aspects of seafaring labor, but it is hoped that the major issues can at least be drawn out to provoke further opinions. However, it should be observed that this article may refer to the theory in political economics, but it is not the intention of this paper to address that theory in particularly, but by means of that to summarize the special characteristics of seafaring labor.

\section{The Concept of Seafaring Labor}

In economics, labor, land, capital and entrepreneurship are considered as the four most important factors of production [5, 6]. To some extent, these four terms by their nature are equivalent to the terms: labor, subjects of labor, instruments of labor and 
entrepreneurship. The combination of subjects of labor and instruments of labor is the means of production. Human beings operate on the subjects of labor, using the instruments of labor, to create a product; or, stated another way, labor acting on the means of production creates a product [7]. The production of any good or service inevitably requires these four types of inputs. The services of factors of production are bought and sold in the market-place. Wages, salaries, rent, interest and profit are no more than the prices of factors of production [8]. The ability of a factor of production to produce output is known as the factor's productivity. It is a technological relationship, between what is fed into the productive apparatus by way of inputs of factor services, and what is turned out by way of product and service. In stating this relationship, it must be noted that production is a flow: it is not just so many units, but so many units per period of time [8]. In markets, entrepreneurs combine labor and other factors to produce goods and services, by which to make a profit and add to a nation's economic output.

Labor is, in the first place, a process in which both man and Nature participate, and in which man of his own accord starts, regulates, and controls the material reactions between himself and Nature [9]. Put another way, labor is a process between human and nature, a process by which human, through his own actions, mediates, regulates and controls the metabolism between himself and nature [10]. According to Marx's theory of labor, as useful activity directed to the appropriation of natural factors in one form or another, labor is a natural condition of human existence, a condition of material interchange between man and nature, and a purposeful activity to produce use value [11]. As use values can become wealth in the society, it is also considered that labor is the source of wealth and culture of the society $[10,12,13]$. Therefore, the substance of labor is a mode of production. In the process the laborer acts on the objects of labor by the means of production, under specific relations of production [14]. Therefore, the labor can be considered as the effort that people contribute to the production of any goods and services. Labor includes both the physical and mental efforts of humans used for the production of goods and services. It is also defined as the collective or generic name given to all the various productive services provided by human beings, including physical effort, skills, intellectual abilities and applied knowledge [15]. The payment for someone else's labor and all income received from one's own labor is wages and salaries.

In shipping, the seafaring labor is applied to transportation and communication, and the product of labor is not a material commodity but a service [16]. From the standpoint of Marx's definition of productive labor, it is viewed that the laws of commodity production held for transportation as for any other industry. "If the job of protecting freight and passengers on roads were not carried out by the state police but rather by private transportation bureaus which maintained armed protection by hired worker, the members of such bureaus would be productive laborers" [17]. In neo-classical economics production refers to the output of services as well as goods, and output in shipping is a function of inputs, such as labor and capital [18]. The productivity is generated as the relationship between the capital input and not merely the output of goods but also services in various forms [19]. As a mode of production is a specific combination of productive forces and relations of production, the characteristics of seafarers' labor reflect the characteristics of the mode of maritime production.

\section{Seafaring Labor in the Maritime Means of Production}

In every kind of labor process, there are three elementary factors: the labor, the subject of labor and the instrument of labor [20]. The combination of the instruments of labor with subjects of labor are the means of production, which can be defined as anything in the outside world which is utilized to produce goods and services so as to satisfy human material needs and 
maintain existence [21]. It refers to physical, non-human inputs used in production, including the factories, machines, tools, natural resources and infrastructure used to produce wealth [22]. Both the labor and means of production are essential ingredients of any production process [23]. In the mode of maritime production, the seafarer is the laborer while the ship and cargo constitute the special type of means of production. The combination of the seafarer's labor and the means of production represent the contemporary maritime productive forces.

\subsection{Ship-The Maritime Instrument of Labor}

An instrument of labor is considered as a thing, or a complex of things, which the laborer interposes between himself and the subject of his labor, and which serves as the conductor of his activity [24]. In the maritime industry, the ship is the most important instrument of labor. There are two main parts to a ship: the hull and the machinery. The hull is the actual shell of a ship including the superstructure, the engine room houses the ballast tanks and the cargo holds. The machinery part includes not only the main engines required to drive it, but also the ancillary equipment serving the electrical installations, winches, pumps and refrigerated accommodation. In order to make sure a ship is in a functional condition, it is also required to install various equipment, for instance, propeller system, cargo handling system, navigation equipment, communication equipment and so forth [25]. In an era of high-tech, according to various conventions related to safety and security at sea, it is also mandatory for all ships to have Global Navigation Satellite system, Automatic Identification System and Voyage Data Recorders and so on. In addition, in order to deal with unexpected emergency, the ship is also equipped with life-saving and fire-fighting apparatus. As a qualified worker onboard, a seafarer needs to be familiar with all the machineries, equipment and apparatus relevant to his work aboard. The overall purpose of a ship is to transport cargo from one place to another [26]. Only by transportation of cargo can she fulfill the ability as ani nstrument of labor. The cargo capacity, service speed and bunker consumption are the most important factors determining a ship's productivity. In order to improve that, the new technology, high speed engine, increased size and tonnage are introduced in ship design and shipbuilding practice. All these factors bring about short time in port and fast turnaround times, which exacerbate the working condition as well as workload of the seafarer [27].

\subsection{Cargo-The Subject of Seafaring Labor}

The subject of labor refers to everything to which the people's labor is applied. In the shipping industry, the subjects of seafarers' labor are the cargoes which should be transported from one port to another. There are mainly two aspects in the seafarers' duty related to the carriage of cargo at sea. On the one hand, before the ship receive any cargo, the seafarer needs to ensure the ship is seaworthy and make the cargo holds, refrigerating and cool chambers and all other parts of the ship in which cargo are carried, fit and safe for the reception, carriage and preservation. On the other hand, after receiving the cargo, the seafarers shall properly and carefully load, handle, stow, carry, keep, care for and discharge the cargo carried.

The features of cargo handling are pretty different from that of shore-based industries. First, the types of cargo are various subjected to the assignments of different voyages. Basically, there are three types of cargoes: bulk, general and specialized cargo. Bulk cargo includes iron ore, steel, timber, coal, oil and so on. With regard to general cargo, typically there are boxes, bales, machinery, steel products and bagged malting barley. Some other cargoes which are not fit comfortably in either the container or the bulk shipping systems are categorized as specialized cargo, such as cars and wheeled vehicles and liquefied gases [28]. As a qualified seafarer working onboard, he needs to be capable of handling various kinds of cargoes. Secondly, in an era when ship-owners are endeavoring to reduce 
their crew costs, the number of crew is always reduced to the minimum number. In the middle of cargo handling, it is very common to encounter unexpected delays or urgent situations, for instance, breakdown of hatch cover or cargo gear. Under such unusual circumstance, there are not more hands available to help. The seafarers have to work overtime until all backbreaking work is completed as required by the ship-owner. In addition, when handling hazardous and poisonous cargo, emergency incident may happen on board ship now and then [29]. In circumstances of injury or illness caused by harmful substances, even though there is a person in charge of medical treatment aboard, it is not of the kind that would be provided by a medical doctor on land.

\section{Conclusion}

In the maritime industry, seafaring labor plays the central role in generating shipping production. Centering around seafaring labor, a number of elements in maritime industry differ from that on land based industry. First of all, the ship is not only the means of labor, but also the place where the seafarers live, sleep and socialize independently far from the land. The seafarer's work onboard is very complex, lengthy and highly stressed. Moreover, the seafarer has to deal with hazardous cargo and urgent situation every now and then. On the other hand, the seafaring labor relation is very special. The shipowners provide not only the means of production, but also the means of livelihood, including the accommodation, food and recreational facilities. However, it is very difficult for the shipowner to supervise and monitor the real situation onboard effectively albeit the huge capital they invest. As an isolated group far from land, the seafarers are also the most difficult to organize trade union through which to bargain with their employer. Furthermore, due to special working and living conditions, the reproduction of seafaring labor is constrained by many factors. However, as a scare resource, the number of skilled seafarers from many countries has declined and there is a considerable shortage for certain grades of officers.

In the preceding context many an issues about the characteristics of seafaring labor have been discussed from the perspective of economics. Based on the relations between the economics base and superstructure, it is indicated that in the social production, the law, policy and regulatory system should adapt to the economic base, which includes the productive forces and relations of production. Through the discussion of a number of elements centering on the seafaring labor in maritime industry, the main features of maritime economic base are to be characterized.

\section{References}

[1] Rigby, S. H. 1998. Marxism and History: A Critical Introduction. 2nd ed. Manchester: Manchester University Press.

[2] Sanderson, S. K. 2001. The Evolution of Human Sociality: A Darwinian Conflict Perspective. Boston: Rowman \& Littlefield Publishers, Inc.

[3] Williams, R. 2005. Culture and Materialism: Selected Essays. London: Verso.

[4] Manners, R. A., and Kaplan, D. eds. 2009. Anthropological Theory. Chicago: Aldine Pub. Co.

[5] Carbaugh, R. J. 2011. Contemporary Economics: An Applications Approach. 6th ed. New York: M.E. Sharpe, Inc.

[6] Anderton, A. 2000. Economics. 3rd ed. London: Dorling Kindersley Ltd.

[7] Evans, M. 1975. Karl Marx. Bloomington: Indiana University Press.

[8] Lipsey, R. G., and Harbury, A. C. 1992. First Principles of Economics. 2nd ed. Oxford: Oxford University Press.

[9] Eister, J. 1986. Karl Marx: A Reader. Cambridge: Cambridge University Press.

[10] Simon, L. H. ed. 1994. Karl Marx: Selected Writings. Indianapolis: Hackett Publishing Company.

[11] Marx, K., and Engels, F. 1975. Capital: Critique of Political Economy-Vol. 1. Beijing: The People's Press.

[12] Brown, H. A. 2012. Marx on Gender and the Family: A Critical Study. Leiden: Brill.

[13] Morgan, M. L. ed. 2005. Classics of Moral and Political Theory. 4th ed. Indianapolis: Hackett Publishing Company.

[14] Carrier, J. G. ed. 2012. A Handbook of Economic Anthropology. Cheltenham: Edward Elgar Publishing Limited. 
[15] Hussain, T. 2010. Engineering Economics. New Delhi: Mehra Offset Press.

[16] Sager, E. W. 1996. Seafaring Labour: The Merchant Marine of Atlantic Canada, 1820-1914. Montreal: McGill-Queen's University Press.

[17] Rubin, I. I. 2008. Essays on Marx's Theory of Value. Delhi: Aakar Books.

[18] Itoh, M. 1988. The Basic Theory of Capitalism: The Forms and Substance of the Capitalist Economy. New Jersey: Barnes \& Noble Books.

[19] Crabbe, P., Holland, A., Ryszkowski, L., and Westra, L. eds. 1999. Implementing Ecological Integrity: Restoring Regional and Global Environmental and Human Health. Dordrecht: Kluwer Academic Publishers.

[20] Marx, K., Engels, F., and Levitsky, S. L. 1996. Das Kapital: A Critique of Political Economy. Washington: Regnery Gateway.

[21] Morrison, K. 2006. Marx, Durkheim, Weber: Formations of Modern Social Thought. 2nd ed. London: SAGE Publications Ltd.
[22] Henslin, J. M. 2002. Essentials of Sociology: A Down-to-Earth Approach. Boston: Taylor \& Francis.

[23] Russell, J. W. 1989. Modes of Production in World History. London: Routledge.

[24] Gingell, J., Little, A., and Winch, C. eds. 2000. Modern Political Thought: A Reader. London: Routledge.

[25] Branch, A. E. 2007. Elements of Shipping. 8th ed. New York: Routledge.

[26] Coupe, A. D., and Walsh, C. J., Stanberry, B. A., and Boerne, G. L. 1999. Voyages of Abuse: Seafarers, Human Rights and International Shipping. London: Pluto Press.

[27] Dimitrova, D. N. 2010. Seafarers' Rights in the Globalized Maritime Industry. London: Kluwer Law International.

[28] Stopford, M. 2009. Maritime Economics. 3rd ed. Oxon: Rutledge.

[29] Rao, P. G., and Raghavan, K. V. 1996. "Hazard and Risk Potential of Chemical Handling at Ports." Journal of Loss Prevention in the Process Industries 9 (3): 199-204. 